\title{
Ethnomedicinal survey among Kani Tribes and traditional healers in Selected Tribal populations of Trivandrum district
}

\author{
Research Article
}

\section{Parvathy $\mathbf{R S}^{1 *}$, Sivakkumar S ${ }^{2}$, Meenakumari $\mathbf{R}^{3}$}

\author{
1. PG Scholar, 2. Associate Professor, 3 HOD/Director, \\ Department of Gunapadam, National Institute of Siddha, Ministry of AYUSH, Chennai-600047.
}

\begin{abstract}
Indian tribes constitute around $8.3 \%$ of the total population. The health problems of tribal communities are influenced by the interaction of various socioeconomic and political factors. An attempt is made to document the traditional knowledge of the Kani tribes in the floristically rich Peringamala panchayath of Thiruvananthapuram district. The investigation revealed that the Kani tribes were using 127 species of ethnomedicinal plants, belonging to 57 families. The most cited family was Fabaceae and leaves were the most frequently used plant parts for the treatment of various diseases. Some medicinal plants used by Kani tribes which are included in the list of rare and endangered categories, such as Aristolochia tagala, Holostemma adakodien, Entada scandens, Anaphyllum beddomeii, decalepsis arayalpathra which are vanishing from the tribal settlement areas. So special attention should be given to cultivate and conserve these rare medicinal plants by making them available for mass cultivation, either through conventional methods or other non-conventional methods like micropropagation. The study showed that the Kani tribes have good knowledge about medicinal plants that have been passed orally from generation to generation. Current healers may be the final generation of Kani tribal healers. Due to rapid socio-economic and cultural changes, there is a possibility of losing the treasure of tribal knowledge in near future. The wealth of this tribal knowledge would lead to a greater potential for the Indian system of medicine towards new drug discovery and development.
\end{abstract}

Key Words: Traditional knowledge; Ethno-medicine; Kani tribes.

\section{Introduction}

India is one of the leading countries in Asia in terms of the wealth of traditional knowledge. Our country is having rich vegetation with a wide variety of plants, because of the extreme variations in geographical and climate conditions prevailing in the country. In the current situation, ethnomedicinal studies are relevant, because it brings to light the direct relationship of plants with human. It has offered immense scope and opportunities for the development of new drugs. Tribes constitute about $8.3 \%$ of the nation's population. (1) Some of the tribal medicines have already been Inco-operated in the organized system of medicines, yet large numbers of folk medicines have remained prevalent to certain tribal pockets as a guarded secret. The study area, Peringamala Panchayath is one of the important Panchayath in the Thiruvananthapuram district. "Kanikkars" are the earliest settlers of Peringamala Panchayath. Some of the tribal communities have come

\section{* Corresponding Author:}

Parvathy RS

PG Scholar,

Department of Gunapadam,

National Institute of Siddha,

Ministry of AYUSH, Chennai. India.

Email Id: parurs94@gmail.com into the mainstream, most of them are far from development and education.

Kani people inhabit the area around Agasthiyakutam and Mahendragiri peaks of the western part of the Adimali hills in Idukki. There are 1317 Kanikkaran families spread over eighteen Oorukkuttams (Hamlet) in this Panchayath. (2) Due to modernization, the traditional healing practices are now fast disappearing and there is a tendency to discard their traditional lifestyle and gradual migration to the mainstream. This is particularly true in Kani tribal communities in Peringamala Panchayath. Kerala is known to be a museum of different ethnic tribal groups, and they are continuing traditional practice with the help of available biological resources. Tribal communities have distributed in different parts of Kerala and they have a different lifestyle. The tribes possess traditional knowledge about the uses of medicinal plants and employ different plants for curing diseases. An abundance of ethnomedicinal information on plant uses can be found in the scientific literature but has not yet been compiled into a usable form. (3) Preserving the traditional knowledge of tribal communities and proper documentation of the ethnomedicinal uses of medicinal plants are useful and need of the hour. Traditional practitioners can also follow the quality treatment modalities from Kani tribes if it seems to be effective. 
Traditionally, the Kani tribes are known to be nomadic communities. They are native to the tropical forests of the Agasthyamalai hills in the Western ghats with a population of nearly 25,000 . They were called 'Kanikkar' by the Sage Agastya, connoting, hereditary proprietor of the land. (4) Among tribal groups, the physicians are known as Plathi, they are the exclusive holders of tribal knowledge. Only Plathi has the right to transfer this knowledge following their customs. Now the government health centers have become more accessible and Plathi's role has become less important in this community. The Kanikudi or Kanipat (Settlements) is headed by a Muttukani who have great powers among tribes. However, over time, this traditional system of governance was largely replaced by the Panchayati Raj system of developed village administration. Today, Kani tribes live in the different tribal hamlets around the forest area of Thiruvananthapuram. Nowadays the quality-of-life style of Kani tribes has greatly improved when compared to ancient times. 'Malamkanis' are those living in the interior forest region who are still deprived of the basic amenities of life. There are 5872 Kanikaran families spread over 48 local bodies in 7 districts. (5)

Traditional practitioners perform an important role in providing health care to the inhabitants of Kerala. Traditional practitioners are part-time folk medical practitioners. They use medicinal plants and formulations and also may include animal parts, insects, and minerals. Traditionally trained Siddha healers to play an important role in rural health care by treating skin allergies, renal calculi, and poisonous bites. Evidence-based therapies have shown remarkable success in healing acute as well as a chronic disease. Arogya Pacha (Trichopus zeylanicus) (6) used by the Kani tribe of Kerala epitomizes the relevance of ethnomedicinal research and from this plant, scientists formulated a health drink known as 'Jeevani'. It is known for its immunity-enhancing, anti-fatigue, liver-protective, and, DNA-protective properties. (7) Studies have also proved its varied spectrum of pharmacological properties such as antioxidant, aphrodisiac, anti-microbial, anti-inflammatory, immunomodulatory, anti-tumor, anti-ulcer, antihyperlipidaemic, hepatoprotective, and anti-diabetic. One of the main flaws of Traditional medicines is due to the unavailability of comprehensive and authentic information on the practice. Documentation of indigenous knowledge, in this type of study, is important for the conservation and utilization of biological resources. Also, there is a possibility of losing a wealth of traditional knowledge in near future. So, it's our responsibility to acquire and preserve the traditional system of medicine and conservation of rare endangered species. This study mainly focuses to investigate the medicinal efficacies and plant utilization among Kani tribes and local traditional healers in selected tribal settlements of Peringamala Panchayath, Thiruvanthapuram district. So, the documentation of this evidence will be more valuable for future generations and the scientific approach of wider use of traditional knowledge.

\section{Materials and methods}

This study was conducted as a communitybased survey which comes under cross-sectional study by using a cluster sampling method. There are 18 Kani settlements in Peringamala Panchayath, Vamanapuram block, Thiruvananthapuram district as per the list obtained from the Integrated Tribal Development Project (ITDP). Peringamala is the largest panchayath in the Thiruvananthapuram district and shares its east boundary with Tamilnadu. It is located in the valley of the Ponmudi hills. In ancient times, this area was reputed for various forest products like honey, pepper, arachenut, etc. Agriculture is the main occupation of this locality. $(8,9)$ From each settlement, 10 households were selected and in total 180 houses were enrolled for this study.

Fig.no - 1: Map of Peringamala Panchayath; Kerala.

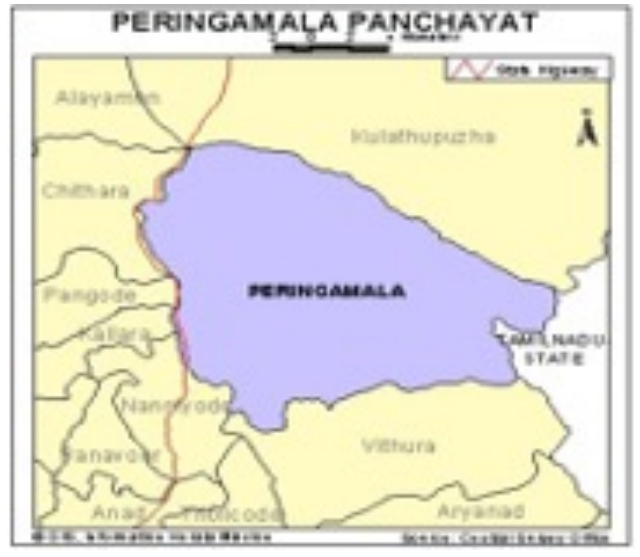

\section{Ethnomedicinal data collection - Mode of interview}

There is no detailed information about 18 settlements of Peringamala Panchayath in published form. So that it deserves great attention for ethnomedicinal research on these settlements. Informants like tribes (Kanikkar) were selected in the cluster sampling method in the study area. Besides efforts were made to approach as were traditional practitioners as possible. Information was collected by interviewing them and filling a questionnaire for documentation. The information was gathered from Kani tribes and traditional healers who use plants for self-medication and to treat others. The reliability of the information was assessed after repeated verification. The information was collected during the daytime only. At the end of the interview, information was noted in written form. Data collection and analysis were simultaneously done.

\section{Results and discussion}

The present investigation comprises the Kani tribes in 18 settlements of Peringamala Panchayath were using 127 species of ethnomedicinal plants which are belonging to 57 families. The plants documented are arranged alphabetically by their botanical name with family, Malayalam name, Tamil name, ethnomedicinal uses were tabulated in Table.no - 1. Out of 127 medicinal plants, 18 them were included in the list of 
rare and endangered categories Such as Aristolochia tagala, Holostemma adakodien, Entada scandens, Begonia malabarica,

Anapyllum beddomeii, decalepsis arayalpathra are vanishing from the tribal settlement areas. So special attention should be needed to conserve these plants through conventional methods or other nonconventional methods like micropropagation.

Table.no - 1: Ethnomedicinal plants used by the Kani groups of 18 tribal settlements of Peringamala panchayath.

\begin{tabular}{|c|c|c|c|c|}
\hline SI. No & $\begin{array}{l}\text { Botanical } \\
\text { Name/ Family }\end{array}$ & $\begin{array}{l}\text { Vernacular } \\
\text { Name }\end{array}$ & Tamil Name & $\begin{array}{l}\text { Ethnomedicinal Uses } \\
\text { (Medicinal uses reported by Kani tribes in the } \\
\text { present area) }\end{array}$ \\
\hline 1 & $\begin{array}{l}\text { Abrus precatorius Linn. } \\
\text { (Fabaceae) }\end{array}$ & Kunnikuru & Kunti & $\begin{array}{l}\text { Seed is made into powder; which is used in skin } \\
\text { disease. Coconut oil preparations are used to treat } \\
\text { Rheumatism. }\end{array}$ \\
\hline 2 & $\begin{array}{l}\text { Abutilon indicum (L.) } \\
\text { (Malvaceae) }\end{array}$ & Thutti & Thutti & $\begin{array}{l}\text { Leaves are gently fried on castor oil and apply to } \\
\text { inflamed areas. It is also good for piles. } \\
\text { Leaves paste mixed with turmeric is applied on } \\
\text { wounds. }\end{array}$ \\
\hline 3 & $\begin{array}{l}\text { Abelmoschus moschatus (L.) } \\
\text { (Malvaceae) }\end{array}$ & Kasthurivenda & Kattu kasthuri & $\begin{array}{l}\text { Improves digestion } \\
\text { Bad odor (halitosis) }\end{array}$ \\
\hline 4 & $\begin{array}{l}\text { Acacia catechu }(L . f) \\
\text { (Fabaceae) }\end{array}$ & Karungali & Karungali & $\begin{array}{l}\text { A piece of wood boiled in water is good for lower } \\
\text { blood sugar levels. }\end{array}$ \\
\hline 5 & $\begin{array}{l}\text { Acalphya indica L. } \\
\text { (Euphorbiaceae) }\end{array}$ & Poochamayakki & Kuppaimeni & $\begin{array}{l}\text { Cough with expectoration. It is an ingredient in a steam } \\
\text { bath. }\end{array}$ \\
\hline 6 & $\begin{array}{l}\text { Acorus calamus } L . \\
\text { (Araceae) }\end{array}$ & Vayambu & Vasambu & $\begin{array}{l}\text { It is useful for the treatment of skin infections such as } \\
\text { eczema and scabies. Given in children to improve } \\
\text { speech quality. }\end{array}$ \\
\hline 7 & $\begin{array}{l}\text { Achyranthes apsera } L . \\
\text { (Amaranthaceae) }\end{array}$ & Kadaladi & Nayuruvi & $\begin{array}{l}\text { It is an ingredient in a steam bath. Applying extract of } \\
\text { its fruit and seed is good for snake bites. }\end{array}$ \\
\hline 8 & $\begin{array}{l}\text { Aegele marmelos (L.) } \\
\text { Correa } \\
\text { (Rutaceae) }\end{array}$ & Koovalam & Vilvam & $\begin{array}{l}15 \mathrm{ml} \text { leaf extract is taken orally, twice a day to cure } \\
\text { diabetes. } \\
\text { Fruit juice is a good remedy for constipation. It is used } \\
\text { to cure cough, swelling, poisonous bites. Herbal hair oil } \\
\text { is made from its leaves. }\end{array}$ \\
\hline 9 & $\begin{array}{l}\text { Aerva lanata(L.)Juss.ex } \\
\text { schult } \\
\text { (Amaranthaceae) }\end{array}$ & Cherula & Sirupeelai & $\begin{array}{l}\text { The whole plant is used for urinary infections, kidney } \\
\text { stones, and infections. } \\
\text { Leaf extract mixed with milk is good for pregnant } \\
\text { ladies. Especially after } 7 \text { months. }\end{array}$ \\
\hline 10 & $\begin{array}{l}\text { Aloe barbedensis Mill. } \\
\text { (Liliaceae) }\end{array}$ & Kattarvazha & Kumari & $\begin{array}{l}\text { Fresh juice is externally applied for inflammations. It is } \\
\text { also used to prepare hair tonic. }\end{array}$ \\
\hline 11 & $\begin{array}{l}\text { Alpinia galanga }(\text { L.) } \\
\text { (Zingiberaceae) }\end{array}$ & Chittaratha & Arathai & $\begin{array}{l}\text { Vatha diseases, Kapha disorders, an ingredient in the } \\
\text { steam bath. }\end{array}$ \\
\hline 12 & $\begin{array}{l}\text { Alstonia scholaris (L.) } \\
\text { (Apocynaceae) }\end{array}$ & Ezhilampala & Ezhilampalai & The milky latex is externally applied for inflammations \\
\hline 13 & $\begin{array}{l}\text { Anacardium occidentale } L . \\
\text { (Anacardiaceae) }\end{array}$ & Kasumavu & Munthiri & $\begin{array}{l}\text { The fruit extract is used to cure chronic diarrhea and } \\
\text { dysentery. }\end{array}$ \\
\hline 14 & $\begin{array}{l}\text { Anisochilus } \\
\text { carnosus (L.f) Wall } \\
\text { (lamiaceae) }\end{array}$ & Panikoorkka & Karpooravalli & $\begin{array}{l}\text { Productive cough, headache. Leaf juice mixed with } \\
\text { honey is good for intestinal parasites, fever. It also } \\
\text { gives relief from urinary infection and stomach pain. }\end{array}$ \\
\hline 15 & $\begin{array}{l}\text { Aristolochia Indica L. } \\
\text { (Aristolochiaceae) }\end{array}$ & Garudakodi & Eecharamooli & Root and leaf paste is used for Snake poison \\
\hline 16 & $\begin{array}{l}\text { Asparagus racemosus Wild } \\
\text { (Lilliaceae) }\end{array}$ & Shatavari & $\begin{array}{l}\text { Thannervittan } \\
\text { Kizhangu }\end{array}$ & $\begin{array}{l}\text { Improves lactation, } \\
\text { Stomach disorders. } \\
\text { An ingredient in Vara kuzhambu used by Kani tribes } \\
\text { for ulcers, swelling }\end{array}$ \\
\hline 17 & $\begin{array}{l}\text { Azadirachta indica A.Juss } \\
\text { (Meliaceae) }\end{array}$ & Aaryaveppu & Vembu & Leaf paste is applied externally for chickenpox. \\
\hline 18 & $\begin{array}{l}\text { Bacopa monnieri (L.) } \\
\text { (Scrophulariaceae) }\end{array}$ & Brahmi & Neerbrahmi & $\begin{array}{l}\text { Oil preparation of leaf juice is applied on the head to } \\
\text { cure fever and epilepsy. It also promotes hair growth.it } \\
\text { helps to reduce inflammations. }\end{array}$ \\
\hline 19 & $\begin{array}{l}\text { Biophytum sensitivum (L.) } \\
\text { (Geraniaceae) }\end{array}$ & Mukkutti & Nilaccurunki & $\begin{array}{l}\text { Leaf preparations are given to ladies after delivery to } \\
\text { cure uterine problems. Leaf and root extract are used to } \\
\text { regulate menstrual bleeding. Root extract mixed with } \\
\text { butter or ghee is good for wasp toxin. Leaf extract is } \\
\text { good for skin burns. }\end{array}$ \\
\hline
\end{tabular}


Parvathy RS et.al., Ethnomedicinal survey among Kani Tribes of Trivandrum district

\begin{tabular}{|c|c|c|c|c|}
\hline 20 & $\begin{array}{l}\text { Boerhavia diffusa L. } \\
\text { (Nyctaginaceae) }\end{array}$ & Thazhuthama & Mukkirattai & $\begin{array}{l}\text { Ilai thoran (Stir-fried leaves) is effective to cure } \\
\text { rheumatism and swelling. It is one of the ingredients in } \\
\text { the steam bath. Drinking boiled water of its root is } \\
\text { good for diabetes, urinary infection, arthritis. }\end{array}$ \\
\hline 21 & $\begin{array}{l}\text { Cardiospermum } \\
\text { halicacabum L. } \\
\text { (Sapindaceae) }\end{array}$ & Uzhinja & Mudakattran & $\begin{array}{l}\text { It is used for constipation, fever. An ingredient in the } \\
\text { steam bath }\end{array}$ \\
\hline 22 & $\begin{array}{l}\text { Calophyllum inophyllum L. } \\
\text { (Caryophyllaceae) }\end{array}$ & Punna & Punnai & $\begin{array}{l}\text { Root decoction is used to treat ulcers, wounds. } \\
\text { Heated leaves are applied as a poultice to cuts, sores, } \\
\text { ulcers, boils, and skin rash. }\end{array}$ \\
\hline 23 & $\begin{array}{l}\text { Caesalpinia bonduc L. } \\
\text { (Caesalpiniaceae) }\end{array}$ & Kazhachikai & Kazharchikkai & $\begin{array}{l}\text { Seed oil is used to treat rheumatism. } \\
\text { Leaves and seeds, after roasting with castor oil, are } \\
\text { applied externally to inflammations. }\end{array}$ \\
\hline 24 & $\begin{array}{l}\text { Calotropis gigantea (L.) } \\
\text { (Asclepiadaceae) }\end{array}$ & Erukku & Erukku & $\begin{array}{l}\text { Leaf paste is applied externally for wounds. It is an } \\
\text { ingredient in the steam bath. Stem latex is directly } \\
\text { applied for itching, rashes on the skin. }\end{array}$ \\
\hline 25 & $\begin{array}{l}\text { Capsicum frutescens } L . \\
\text { (Solanaceae) }\end{array}$ & Kantharimilagu & Milagai & It is good for reducing high cholesterol. \\
\hline 26 & $\begin{array}{l}\text { Cassia fistula L. } \\
\text { (Caesalpinioideae) }\end{array}$ & Kanikonna & Sarakontrai & Bath in water boiled with wood is good for psoriasis. \\
\hline 27 & $\begin{array}{l}\text { Centella asiatica }(L .) \\
\text { (Umbelliferae) }\end{array}$ & Kudangal & Vallarai & $\begin{array}{l}\text { Leave paste is in taken for Diabetes, worm infestations. } \\
\text { Leaf juice (1teaspoon) mixed with butter is good to } \\
\text { improve immune power in children and mental ability. }\end{array}$ \\
\hline 28 & $\begin{array}{l}\text { Chlorophytum laxum R.Br } \\
\text { (Liliaceae) }\end{array}$ & $\begin{array}{l}\text { Neeroottikizhan } \\
\text { gu }\end{array}$ & $\begin{array}{l}\text { Vellai musali, } \\
\text { thiravanthi }\end{array}$ & $\begin{array}{l}\text { Tuber paste is applied over the affected area for } \\
\text { inflammation. }\end{array}$ \\
\hline 29 & $\begin{array}{l}\text { Cissus quadrangularis } L . \\
\text { (Vitaceae) }\end{array}$ & $\begin{array}{l}\text { Changalam } \\
\text { Paranda }\end{array}$ & Pirandai & $\begin{array}{l}\text { It is used for the treatment of piles and rheumatism. } \\
\text { Applying powdered dry stem with tamarind on the } \\
\text { fractured site to heal the fracture. }\end{array}$ \\
\hline 30 & $\begin{array}{l}\text { Cissampelos pereira L. } \\
\text { (Menispermaceae) }\end{array}$ & Malathangi & Malathanni & $\begin{array}{l}\text { The leaf preparations used for post-partum } \\
\text { management (uterine disorders). }\end{array}$ \\
\hline 31 & $\begin{array}{l}\text { Clausena anisate (Willd) } \\
\text { (Rutaceae) }\end{array}$ & $\begin{array}{l}\text { Kattukariveppil } \\
\text { a }\end{array}$ & $\begin{array}{l}\text { Kattu } \\
\text { kariveppilai }\end{array}$ & Leaf preparations are used for worm infestations. \\
\hline 32 & $\begin{array}{l}\text { Clerodendrum inerme (L.) } \\
\text { Gaertn. } \\
\text { (Verbenaceae) }\end{array}$ & Sangankuppi & Isangu & $\begin{array}{l}\text { The leaf preparations used for post-partum } \\
\text { management (uterine disorders). }\end{array}$ \\
\hline 33 & $\begin{array}{l}\text { Clerodendrum infortunatum } \\
L . \\
\text { (Verbenaceae) }\end{array}$ & Peruvalam & Kanduparangi & $\begin{array}{l}\text { It is an ingredient in the steam bath. Leaf paste is used } \\
\text { as an external application for wounds. }\end{array}$ \\
\hline 34 & $\begin{array}{l}\text { Clerodendrum serratum(L.) } \\
\text { (Verbenaceae) }\end{array}$ & Cheruthekku & Siruthekku & $\begin{array}{l}\text { Root and bark preparations are used for pediatric } \\
\text { diseases. }\end{array}$ \\
\hline 35 & $\begin{array}{l}\text { Clitoria ternatea L. } \\
\text { (Fabaceae) }\end{array}$ & Sangupushpam & Kakkattan & Leaf paste is used for skin diseases. \\
\hline 36 & $\begin{array}{l}\text { Curcuma longa L. } \\
\text { (Zingiberaceae) }\end{array}$ & Manjal & Manjal & $\begin{array}{l}\text { The unripened tuber is a good treatment for an insect } \\
\text { bite. }\end{array}$ \\
\hline 37 & $\begin{array}{l}\text { Curculigo orchioides Gaertn } \\
\text { (Amaryllidaceae) }\end{array}$ & Nilappana & Nilappanai & $\begin{array}{l}\text { The tuber is used to promote lactation. Tuber powder is } \\
\text { mixed with coconut milk and made into pills and } \\
\text { consumed for diabetes. } \\
\text { The root is ground and applied over swelling. }\end{array}$ \\
\hline 38 & $\begin{array}{l}\text { Curcuma amada Roxb. } \\
\text { (Zingiberaceae) }\end{array}$ & Manga inji & Mangaiinji & $\begin{array}{l}\text { Used to cure skin diseases, stomach pain, gas trouble, } \\
\text { constipation }\end{array}$ \\
\hline 39 & $\begin{array}{l}\text { Curcuma aromatica Salisb. } \\
\text { (Zingiberacaea) }\end{array}$ & $\begin{array}{l}\text { Kasthoorimanja } \\
l\end{array}$ & $\begin{array}{l}\text { Kasthooriman } \\
\text { jal }\end{array}$ & $\begin{array}{l}\text { It is used as an antidote to snake bites and is useful for } \\
\text { sprains, cuts, swelling }\end{array}$ \\
\hline 40 & $\begin{array}{l}\text { Cyclea peltata } \\
\text { Hook.f\&Thomas } \\
\text { (Menispermaceae) }\end{array}$ & Pada thali & Padathali & $\begin{array}{l}\text { Leaf paste is applied directly over the burns. } \\
\text { It is also used for dandruff and skin disorders. } \\
\text { Root powder boiled with curd, intake one spoon daily } \\
\text { to cure piles. applying a thick paste of its leaves on the } \\
\text { scalp is good for eye diseases and will give coolness to } \\
\text { the eyes. }\end{array}$ \\
\hline 41 & $\begin{array}{l}\text { Cynodon dactylon (L.) pers } \\
\text { (Poaceae) }\end{array}$ & Karuka & Aruganpul & Leaf juice is used to stop nasal Bleeding(epistaxis) \\
\hline 42 & $\begin{array}{l}\text { Datura alba F.Muell } \\
\text { (Solanaceae) }\end{array}$ & Ummam & Oomathai & $\begin{array}{l}\text { Dried flower is made into powder and used to treat } \\
\text { bronchial asthma. }\end{array}$ \\
\hline 43 & $\begin{array}{l}\text { Delonix elata (L.) } \\
\text { (Fabaceae) }\end{array}$ & Vatham kolli & $\begin{array}{l}\text { Vatha } \\
\text { narayanan }\end{array}$ & Vatha disorders. It is an ingredient in a steam bath. \\
\hline 44 & $\begin{array}{l}\text { Desmodium gyrans (L.f)DC } \\
\text { (Fabaceae) }\end{array}$ & $\begin{array}{l}\text { Ramanama } \\
\text { Pacha }\end{array}$ & Thozhukanni & It is used in the treatment of sprains. \\
\hline
\end{tabular}


International Journal of Ayurvedic Medicine, Vol 12 (4), 820-832

\begin{tabular}{|c|c|c|c|c|}
\hline 45 & $\begin{array}{l}\text { Desmodium } \\
\text { triflorum(L.)DC. } \\
\text { (Fabaceae) }\end{array}$ & $\begin{array}{l}\text { Cherupulladi/ } \\
\text { Nilamparanda }\end{array}$ & $\begin{array}{l}\text { Cherupulladi/ } \\
\text { Nilamparanda }\end{array}$ & $\begin{array}{l}\text { Preparations from leaf powder are used for urinary } \\
\text { problems. }\end{array}$ \\
\hline 46 & $\begin{array}{l}\text { Dioscorea triphylla L. } \\
\text { (Dioscoreaceae) }\end{array}$ & $\begin{array}{l}\text { Noorankizhang } \\
u\end{array}$ & - & $\begin{array}{l}\text { Root tuber is the main food of tribes. } \\
\text { It is highly nutritional; it gives strength, vitality to the } \\
\text { body. }\end{array}$ \\
\hline 47 & $\begin{array}{l}\text { Eclipta alba (L.) Hassk. } \\
\text { (Asterceae) }\end{array}$ & Kaiyonni & Karisalai & $\begin{array}{l}\text { Leaf extract mixed with sesame oil is good for } \\
\text { headaches, hair loss. It cures diseases related to } \\
\text { phlegm, arthritis, and worm infestation. }\end{array}$ \\
\hline 48 & $\begin{array}{l}\text { Elephantopus scaber L. } \\
\text { (Asteraceae) }\end{array}$ & Aanachuvadi & Yanaisuvadi & $\begin{array}{l}\text { Leave paste is used to reduce inflammation. The whole } \\
\text { plant is used for the treatment of piles, liver, and } \\
\text { gastrointestinal disorders. }\end{array}$ \\
\hline 49 & $\begin{array}{l}\text { Emilia sonchifolia(L.)DC. } \\
\text { (Asteraceae) }\end{array}$ & Muyalcheviyan & Muyalchevi & $\begin{array}{l}\text { The paste made from the entire plant is used for wound } \\
\text { healing. Leaf extract is dropped into the eyes for } \\
\text { cleaning and for cooling effect. }\end{array}$ \\
\hline 50 & $\begin{array}{l}\text { Euphorbia hirta L. } \\
\text { (Euphorbiaceae) }\end{array}$ & Chithirappala & $\begin{array}{l}\text { Amanpachiras } \\
i\end{array}$ & Used for the treatment of jaundice, diabetes, asthma. \\
\hline 51 & $\begin{array}{l}\text { Evolvulus alsinoides }(L .) L . \\
\text { (Convolvulaceae) }\end{array}$ & Vishnu kiranthi & Vishnu Kranti & $\begin{array}{l}\text { The whole plant is powdered and mixed with jaggery } \\
\text { used for chest infection. } \\
\text { Vishnu kranthi karkam in the size of a gooseberry along } \\
\text { with hot water is a good remedy for malaria. }\end{array}$ \\
\hline 52 & $\begin{array}{l}\text { Ficus benghalensis L. } \\
\text { (Moraceae) }\end{array}$ & Peraal & Aalamaram & The milky juice is used for rheumatism and bruises. \\
\hline 53 & $\begin{array}{l}\text { Ficus religiosa } L . \\
\text { (Moraceae) }\end{array}$ & Arayaal & Arasumaram & Taking leaf decoction twice a daily to control diabetes. \\
\hline 54 & $\begin{array}{l}\text { Ficus glomerata Roxb. } \\
\text { (Moraceae) }\end{array}$ & Atti & Atti & $\begin{array}{l}\text { Bark extract boiled with rice water and administrated } \\
\text { internally for worm infestation. }\end{array}$ \\
\hline 55 & $\begin{array}{l}\text { Gloriosa superba L. } \\
\text { (Colchicaceae) }\end{array}$ & Menthonni & $\begin{array}{l}\text { Kalappaikizha } \\
\text { ngu }\end{array}$ & $\begin{array}{l}\text { Leaf paste is applied externally to treat headaches. } \\
\text { Application of root paste is a remedy for snakebite and } \\
\text { scorpion sting. }\end{array}$ \\
\hline 56 & $\begin{array}{l}\text { Glycyrrhiza glabra L. } \\
\text { (Fabaceae) }\end{array}$ & $\begin{array}{l}\text { Erattimadhura } \\
m\end{array}$ & Athimathuram & $\begin{array}{l}\text { The finely powdered root is mixed with hot water and } \\
\text { administrated orally to treat a cough with } \\
\text { expectoration. }\end{array}$ \\
\hline 57 & $\begin{array}{l}\text { Gossypium arboretum } L . \\
\text { (Malvaceae) }\end{array}$ & Paruthi & Paruthi & Leaf paste is used for chest pain. \\
\hline 58 & $\begin{array}{l}\text { Helicteres isora L. } \\
\text { (Sterculiaceae) }\end{array}$ & $\begin{array}{l}\text { Idampiri } \\
\text { Valampiri }\end{array}$ & Valampurikkai & $\begin{array}{l}\text { Decoction of whole plant part is used for snake bite. } \\
\text { Fruits are stomachic. }\end{array}$ \\
\hline 59 & $\begin{array}{l}\text { Hemidesmus indicus (L.) } \\
\text { (Asclepiadaceae) }\end{array}$ & Naruneendi & Nannari & The extract is used to apply to wounds and sprains. \\
\hline 60 & $\begin{array}{l}\text { Hibiscus rosasinensis } L \text {. } \\
\text { (Malvaceae) }\end{array}$ & Chemparathi & Chemparathai & $\begin{array}{l}\text { Preparations from the flower part are used to cure } \\
\text { bronchial asthma. Oil preparations help to promote hair } \\
\text { growth. }\end{array}$ \\
\hline 61 & $\begin{array}{l}\text { Indigofera tinctoria L. } \\
\text { (Fabaceae) }\end{array}$ & Neelaamari & Avuri & $\begin{array}{l}\text { Coconut oil preparation of leaf juice helps to promote } \\
\text { hair growth. }\end{array}$ \\
\hline 63 & $\begin{array}{l}\text { Justicia gendasussa Burm.f. } \\
\text { (Acanthaceae) }\end{array}$ & Vathakodi & Vathamkolli & It is an ingredient in a steam bath. \\
\hline 64 & $\begin{array}{l}\text { Kaempferia galanga L. } \\
\text { (Zingiberaceae) }\end{array}$ & Kacholam & Thakkolam & $\begin{array}{l}\text { Leaves are made into ash and rubbed over the breast to } \\
\text { treat mastitis after childbirth. } \\
\text { Leaves are chewed for relieving cough. }\end{array}$ \\
\hline 65 & $\begin{array}{l}\text { Lecuas aspera (Willd) } \\
\text { (Lamiaceae) }\end{array}$ & Thumba & Thumbai & $\begin{array}{l}\text { Leaf and flower juice mixed with tamarind is good for } \\
\text { scorpion poison. }\end{array}$ \\
\hline 66 & $\begin{array}{l}\text { Maranta arundinacea L. } \\
\text { (Marantaceae) }\end{array}$ & Koovakizhangu & $\begin{array}{l}\text { Koovaikizhan } \\
\text { gu }\end{array}$ & It is used for the treatment of snake poison. \\
\hline 67 & $\begin{array}{l}\text { Mimosa pudica L. } \\
\text { (Mimosaceae) }\end{array}$ & Thottalvadi & Thottalsinungi & $\begin{array}{l}\text { Whole plant extract mixed with } 10 \mathrm{ml} \text { of coconut milk } \\
\text { is taken the daily morning to cure asthma. } \\
\text { Ground leaves are applied to wounds. } \\
\text { Root extract is good for sprains and bruises. } \\
\text { It is an ingredient in herbal hair oil. }\end{array}$ \\
\hline 68 & $\begin{array}{l}\text { Mimusops elengi L. } \\
\text { (Sapotacaeae) }\end{array}$ & Elanji & Magizham & $\begin{array}{l}\text { Bark decoction is given internally for worm } \\
\text { infestations. It is also used for poisonous bites. }\end{array}$ \\
\hline 69 & $\begin{array}{l}\text { Glinus lotoides L. } \\
\text { (Aizoceae) }\end{array}$ & Cheruppada & $\begin{array}{l}\text { Siru } \\
\text { cheruppadai }\end{array}$ & $\begin{array}{l}\text { Root paste is applied over the skin to treat skin ailments } \\
\text { and pruritis. }\end{array}$ \\
\hline 70 & $\begin{array}{l}\text { Moringa oleifera } L . \\
\text { (Moringaceae) }\end{array}$ & Murunga & Murungai & $\begin{array}{l}\text { Leaves ground with salt and applied over swelling and } \\
\text { rheumatism. }\end{array}$ \\
\hline 71 & $\begin{array}{l}\text { Moringa tinctoria Roxb. } \\
\text { (Moringaceae) }\end{array}$ & Manjanathi & Nuna & Leaf decoction administrated orally to treat dysentery. \\
\hline
\end{tabular}


Parvathy RS et.al., Ethnomedicinal survey among Kani Tribes of Trivandrum district

\begin{tabular}{|c|c|c|c|c|}
\hline 72 & $\begin{array}{l}\text { Murraya koenigii (L.) } \\
\text { (Rutaceae) }\end{array}$ & Kariveppila & Kari vembu & $\begin{array}{l}\text { It is used as an ingredient in many medicinal } \\
\text { preparations for reducing cholesterol levels, high blood } \\
\text { pressure. }\end{array}$ \\
\hline 73 & $\begin{array}{l}\text { Musa paradisiaca } L . \\
\text { (musaceae) }\end{array}$ & Vazha & Vazhai & $\begin{array}{l}\text { Pattai chaaru (bark juice) is given for obesity. Cooked } \\
\text { flowers are given to diabetes. }\end{array}$ \\
\hline 74 & $\begin{array}{l}\text { Naregamia alata Wight\&Arn } \\
\text { (Meliaceae) }\end{array}$ & Nilanarakam & Nilanarakam & Leaf paste is applied over Lipoma. \\
\hline 75 & $\begin{array}{l}\text { Ocimum sanctum L. } \\
\text { (Lamiaceae) }\end{array}$ & Thulasi & Thulasi & $\begin{array}{l}\text { Oil is good to apply on Whitelow, headache, and cold. } \\
\text { A mixture of basil leaves and turmeric is good for } \\
\text { poisonous bites. } \\
\text { Oral administration of leaf extracts helps to decrease } \\
\text { blood glucose levels. }\end{array}$ \\
\hline 76 & $\begin{array}{l}\text { Ocimum sps. L. } \\
\text { (Lamiaceae) }\end{array}$ & Kuzhimundan & - & $\begin{array}{l}\text { Oil preparations of the leaf juice are used to make hair } \\
\text { oil. }\end{array}$ \\
\hline 77 & $\begin{array}{l}\text { Oxalis corniculata } L . \\
\text { (Oxalidaceae) }\end{array}$ & Puliyarila & Puliyarai & $\begin{array}{l}\text { Leaf paste is applied to the forehead to cure headaches. } \\
\text { Leaf juice is mixed with onion juice is applied } \\
\text { externally on warts. }\end{array}$ \\
\hline 78 & $\begin{array}{l}\text { Pergularia daemia(Forssk.) } \\
\text { (Asclepiadaceae) }\end{array}$ & Velipparuthi & Uthamani & $\begin{array}{l}\text { Latex of uthamani (Pergularia daemia) can be applied } \\
\text { for treating boils and wounds. Root decoction is taken } \\
\text { to treat arthritis. Powder from roasted roots or leaves is } \\
\text { applied to wounds. }\end{array}$ \\
\hline 79 & $\begin{array}{l}\text { Phyllantus embilica L. } \\
\text { (Euphorbiaceae) }\end{array}$ & Nelli & Nelli & Fruit juice is good for diabetes. \\
\hline 80 & $\begin{array}{l}\text { Phyllanthus niruri L. } \\
\text { (Euphorbiaceae) }\end{array}$ & Keezhanelli & Keezhanelli & $\begin{array}{l}\text { The whole plant is ground and mixed with coconut } \\
\text { milk and taken for jaundice. } \\
\text { It is used to cure cough, bleeding, stomach pain, } \\
\text { indigestion. } \\
\text { An ingredient in herbal hair oil. It enhances hair growth } \\
\text { and reduces baldness. }\end{array}$ \\
\hline 81 & $\begin{array}{l}\text { Piper betel L. } \\
\text { (Piperaceae) }\end{array}$ & Vettrila & Vettrilai & $\begin{array}{l}\text { Leaf juice mixed with ginger juice and honey is used to } \\
\text { cure asthma. }\end{array}$ \\
\hline 82 & $\begin{array}{l}\text { Piper longum L. } \\
\text { (Piperaceae) }\end{array}$ & Thippili & Thippili & Fruit is used in the treatment of fever, cough. \\
\hline 83 & $\begin{array}{l}\text { Piper nigrum } L . \\
\text { (Piperaceae) }\end{array}$ & Milagu & Milagai & Improves digestive power and promotes appetite. \\
\hline 84 & $\begin{array}{l}\text { Pterocarpus marsupium } \\
\text { Roxb. } \\
\quad \text { (Fabaceae) }\end{array}$ & Karivenga & Vengai & $\begin{array}{l}\text { The inner part of the wood is boiled in sesame oil and } \\
\text { applied to the scalp to prevent premature grey hair. }\end{array}$ \\
\hline 85 & $\begin{array}{l}\text { Ricinus communis L. } \\
\text { (Euphorbiaceae) }\end{array}$ & Avanakku & Amanakku & $\begin{array}{l}\text { It is an ingredient in a steam bath. } \\
\text { Leaf and seed preparations are used in eye diseases, } \\
\text { Vatha diseases, and ear-related problems. } \\
\text { Its fruit is used to make herbal hair oil. }\end{array}$ \\
\hline 86 & $\begin{array}{l}\text { Ruellia Patula Jacq. } \\
\text { (Acanthaceae) }\end{array}$ & $\begin{array}{l}\text { Chilanthi } \\
\text { Pacha }\end{array}$ & $\begin{array}{l}\text { Kiranthinayag } \\
\text { am }\end{array}$ & $\begin{array}{l}\text { Snakebite, wounds, and scabies. Used as a single drug } \\
\text { remedy against the deadly poison of Kaduvachilanthi } \\
\text { (Tiger spider). }\end{array}$ \\
\hline 87 & $\begin{array}{l}\text { Sansevieria roxburghiana } \\
\text { Schult. \& Schult.F } \\
\text { (Lilliaceae) }\end{array}$ & $\begin{array}{l}\text { Sarpapolal } \\
\text { pampatti }\end{array}$ & Marul & Leaves are used for the preparation of earache. \\
\hline 88 & $\begin{array}{l}\text { Salacia reticulata Wight } \\
\text { (Celastraceae) }\end{array}$ & Ponkoranti & Kadalazhinjil & It is used in the treatment of Urinary disorders \\
\hline 89 & $\begin{array}{l}\text { Saraca asoca(Roxb.)W.J.de } \\
\text { Wilde } \\
\text { (caesalpiniaceae) }\end{array}$ & Asokam & Asogu & $\begin{array}{l}\text { The dried stem bark is a remedy for uterine disorders, } \\
\text { dysentery. Oil preparation from the flower is used to } \\
\text { treat psoriasis. }\end{array}$ \\
\hline 90 & $\begin{array}{l}\text { Scoparia dulcis } L . \\
\text { (Plantaginaceae) }\end{array}$ & Kallurukki & Sarakkothini & $\begin{array}{l}\text { It is good for UTI and kidney stones. } \\
\text { Ingredient in hair oil for headache and fever. }\end{array}$ \\
\hline 91 & $\begin{array}{l}\text { Scleria lithosperma }(L .) \\
\text { (Cyperaceae) }\end{array}$ & Vakkathipullu & $\begin{array}{l}\text { Kadenpullu, } \\
\text { katinappul }\end{array}$ & $\begin{array}{l}\text { Tuber is washed, baked, powdered, and mixed with } \\
\text { coconut oil is applied over the infection, Sebaceous } \\
\text { cyst (Maykkuru) }\end{array}$ \\
\hline 92 & $\begin{array}{l}\text { Senna oxidentalis (L.) } \\
\text { (Caesalpinaceae) }\end{array}$ & Oolanthakarai & Oosithakarai & $\begin{array}{l}\text { It is used to cure Kapha disease, asthma, skin diseases, } \\
\text { and anemia. }\end{array}$ \\
\hline 93 & $\begin{array}{l}\text { Sesbania grandiflora (L.) } \\
\text { (Fabaceae) }\end{array}$ & Agasthikeera & Agathi & $\begin{array}{l}\text { Flower extract mixed with cow's milk and used } \\
\text { internally to prevent leucorrhea and uterine disorders. }\end{array}$ \\
\hline 94 & $\begin{array}{l}\text { Sida rhombifolia } L . \\
\text { (Malvaceae) }\end{array}$ & Kuruthotti & Kuruthotti & Root decoction is used to treat rheumatism. \\
\hline 95 & $\begin{array}{l}\text { Solanum surettense Burn.f. } \\
\text { (Solanaceae) }\end{array}$ & $\begin{array}{l}\text { Kandankarichu } \\
\text { nda }\end{array}$ & $\begin{array}{l}\text { Kandan } \\
\text { kathiri }\end{array}$ & Cough with expectoration, tuberculosis. \\
\hline
\end{tabular}


International Journal of Ayurvedic Medicine, Vol 12 (4), 820-832

\begin{tabular}{|c|c|c|c|c|}
\hline 96 & $\begin{array}{l}\text { Smilax chinensis } L . \\
\text { (Smilacaceae) }\end{array}$ & Kariyilanchi & Parangipattai & Root juice is used to cure rheumatism, skin troubles. \\
\hline 97 & $\begin{array}{l}\text { Solanum torvum Sw. } \\
\text { (Solanaceae) }\end{array}$ & Putharichunda & Chundaikkai & Leaf paste is applied externally over wounds. \\
\hline 98 & $\begin{array}{l}\text { Syzygium cumini (L.) } \\
\text { (Myrtaceae) }\end{array}$ & Njaval & Naval & It is good for curing wounds and skin diseases. \\
\hline 99 & $\begin{array}{l}\text { Tamarindus indicum L. } \\
\text { (Fabaceae) }\end{array}$ & Puli & $\begin{array}{l}\text { Puli elai } \\
\text { maram }\end{array}$ & $\begin{array}{l}\text { It is one of an ingredient in the steam bath. Boiled } \\
\text { water of tamarind leaves is good for skin diseases and } \\
\text { tiredness. }\end{array}$ \\
\hline 100 & $\begin{array}{l}\text { Terminalia chebula Retz. } \\
\text { (Brassicaceae) }\end{array}$ & Kadukkai & Kadukkai & $\begin{array}{l}\text { It is an ingredient in the steam bath. } \\
\text { It's also used for rheumatism. }\end{array}$ \\
\hline 101 & $\begin{array}{l}\text { Tinospora cordifolia (Willd) } \\
\text { (Menispermaceae) }\end{array}$ & Chittamruthu & Seenthil & $\begin{array}{l}\text { Leaf extract mixed with } \\
\text { half spoon of turmeric powder is taken for diabetes. }\end{array}$ \\
\hline 102 & $\begin{array}{l}\text { Tragia involvucrata L. } \\
\text { (Euphorbiaceae) }\end{array}$ & $\begin{array}{l}\text { Choriyanam/ } \\
\text { Kodithoova } \\
\end{array}$ & Kanjori & $\begin{array}{l}\text { leaves are roasted and ground with rice, administrated } \\
\text { orally to cure cough. }\end{array}$ \\
\hline 103 & $\begin{array}{l}\text { Tylophora } \\
\text { indica(Burn.f.)Merr. } \\
\text { (Asclepiadaceae) }\end{array}$ & Vallipala & Nanjaruppan & $\begin{array}{l}\text { It is effective for curing asthma. oil preparation is used } \\
\text { to reduce inflammations. }\end{array}$ \\
\hline 104 & $\begin{array}{l}\text { Ventilago maderaspatana } \\
\text { Gaertner. } \\
\text { (Rhamnaceae) }\end{array}$ & $\begin{array}{l}\text { Vembada, } \\
\text { Marapettykody }\end{array}$ & $\begin{array}{l}\text { Surulbattaikko } \\
\text { ti, Vempadam }\end{array}$ & $\begin{array}{l}\text { The powder of stem bark mixed with gingelly oil is } \\
\text { applied externally to treat skin diseases and itches. } \\
\text { Bark paste is used for the treatment of the bone } \\
\text { fracture. }\end{array}$ \\
\hline 105 & $\begin{array}{l}\text { Vernonia cineria(L.)Less } \\
\text { (Asteraceae) }\end{array}$ & $\begin{array}{l}\text { Poovamkurunth } \\
\text { al }\end{array}$ & Neichitti & Leaf juice is used as eye drops against conjunctivitis. \\
\hline 106 & $\begin{array}{l}\text { Vinca rosea } L . \\
\text { (Apocynaceae) }\end{array}$ & Savamnaari & $\begin{array}{l}\text { Nithya } \\
\text { Kalyani }\end{array}$ & $\begin{array}{l}\text { It is used for the treatment of skin diseases such as } \\
\text { acne, eczema, and dermatitis. }\end{array}$ \\
\hline 107 & $\begin{array}{l}\text { Vitex negundo L. } \\
\text { (Verbenaceae) }\end{array}$ & Kari notchi & Notchi & $\begin{array}{l}\text { Oil preparation of leaf extract is applied daily on the } \\
\text { head to cure ear-related disorders. It is an ingredient in } \\
\text { the steam bath. A decoction made from leaves of } \\
\text { Adathodai (Adathoda vassica),Notchi( Vitex negundo) } \\
\text { Milagu ( piper nigrum), karpooravalli(Plectranthus } \\
\text { amboinicus) together intake for curing fever. }\end{array}$ \\
\hline 108 & $\begin{array}{l}\text { Wrightia tinctoria R.Br. } \\
\text { (Apocynaceae) }\end{array}$ & Dhanthapala & Vetpalai & $\begin{array}{l}\text { Latex is used for tooth pain. Ingredient in hair oil. It is } \\
\text { used for skin disorders. }\end{array}$ \\
\hline 109 & $\begin{array}{l}\text { Zingiber officinale Roscoe. } \\
\text { (zingiberaceae) }\end{array}$ & Inji & Inji & $\begin{array}{l}\text { A decoction from } 50 \mathrm{gm} \text { dried ginger and 1liter water } \\
\text { and make it } 100 \mathrm{ml} \text {. consuming } 50 \mathrm{ml} \text { of the decoction } \\
\text { daily will give relief from a heart attack. It is good for } \\
\text { digestion, stomach ache, and gas trouble. }\end{array}$ \\
\hline
\end{tabular}

Collection of indigenous and endangered plant species

\begin{tabular}{|c|c|c|c|c|}
\hline 110 & $\begin{array}{l}\text { Diploclisia glaucescens } \\
\text { (Blume) Diels(11) } \\
\text { (Menispermaceae) }\end{array}$ & $\begin{array}{l}\text { Vattavalli, } \\
\text { Vattoli, } \\
\text { Theepacha }\end{array}$ & $\begin{array}{l}\text { Kottaiyachachi, } \\
\text { Morasankodi. }\end{array}$ & $\begin{array}{l}\text { This plant is used by the Kani tribes to heal burns. The } \\
\text { mixture of Plant leaves, gingelly oil, and coconut oil is } \\
\text { used to heal sprains. }\end{array}$ \\
\hline 111 & $\begin{array}{l}\text { Rauwolfia serpentina (L.) } \\
\text { Benth.exkurz. (12) } \\
\text { (Apocynaceae) }\end{array}$ & Sarpagandhi & Sarpagandha & The root is used for snake bites. \\
\hline 112 & $\begin{array}{l}\text { Anaphyllum beddomei Engl. } \\
(13,14) \\
(\text { Araceae })\end{array}$ & Keerikizhangu & - & $\begin{array}{l}\text { Kani tribes use this plant as food and as well as an } \\
\text { antidote for snakebite. This medicinal preparation is } \\
\text { also used by Malayarayan tribes in the Idukki district } \\
\text { of Kerala. }\end{array}$ \\
\hline 113 & $\begin{array}{l}\text { Thottea siliquosa(Lam)Ding } \\
\text { Hou.(15) } \\
\text { (Aristolochiaceae) }\end{array}$ & $\begin{array}{l}\text { Alpam, } \\
\text { Karelvegam, } \\
\text { Kodaashari, } \\
\text { Kuttivayana, }\end{array}$ & $\begin{array}{l}\text { Kuttivayana, } \\
\text { Kuravankand } \\
\text { amooli }\end{array}$ & $\begin{array}{l}\text { It is used as antivenom and also used to treat diarrhea, } \\
\text { dysentery, often administered with lemon juice. Paste } \\
\text { prepared from the plant with oil is effective against } \\
\text { chronic sores and ulcers. }\end{array}$ \\
\hline 114 & $\begin{array}{l}\text { Ceropegia spiralis Wight } \\
(16) \\
\text { (Apocynaceae) }\end{array}$ & Parayilpandam & - & $\begin{array}{l}\text { The importance given to Ceropegia species by Kani } \\
\text { tribes shows that it has certain effectiveness and } \\
\text { potential medicinal properties. This plant is used in the } \\
\text { treatment of fever, indigestion, and liver diseases. The } \\
\text { corm of this plant is used as food, for blood } \\
\text { purification and syphilis. }\end{array}$ \\
\hline 115 & $\begin{array}{l}\text { Knema attenuate Warb. (17) } \\
\text { (Myristicaceae) }\end{array}$ & $\begin{array}{l}\text { Chennelli, } \\
\text { chorapatri }\end{array}$ & Surapathiri & $\begin{array}{l}\text { Stem bark decoction is used to cure jaundice, chronic } \\
\text { fever. It is an ingredient of Ashwagandhadhi nei used } \\
\text { for breathing difficulty, splenic disorders, etc. }\end{array}$ \\
\hline
\end{tabular}


Parvathy RS et.al., Ethnomedicinal survey among Kani Tribes of Trivandrum district

\begin{tabular}{|c|c|c|c|c|}
\hline 116 & $\begin{array}{l}\text { Chassalia curviflora (Wall.) } \\
\text { (18) } \\
\text { (Rubiaceae) }\end{array}$ & $\begin{array}{l}\text { Vellamundan, } \\
\text { Karuthaamalpp } \\
\text { ori, Yamari, } \\
\text { Vellakur }\end{array}$ & $\begin{array}{l}\text { Kaattu } \\
\text { sirukaapi } \\
\text { patchillai, } \\
\text { Nirvisam }\end{array}$ & $\begin{array}{l}\text { Effective medicine for the treatment of jaundice. It is } \\
\text { believed to be three times more effective than the } \\
\text { commonly used medicinal plant, Keezhanelli } \\
\text { (Phyllanthus fraternus). }\end{array}$ \\
\hline 117 & $\begin{array}{l}\text { Pterospermum rubiginosum } \\
\text { B.Heyne ex wight \& Arn(19) } \\
\text { (Sterculiaceae) }\end{array}$ & $\begin{array}{l}\text { Chittilaplavu, } \\
\text { Ellooti, } \\
\text { Malamthodali }\end{array}$ & $\begin{array}{l}\text { Ponnankai, } \\
\text { Malaitholli }\end{array}$ & $\begin{array}{l}\text { To treat broken bones, Bark is crushed and kept on a } \\
\text { clean cloth (kizhi)and heated over a hot mud utensil at a } \\
\text { mild temperature. It is gently applied over the affected } \\
\text { area for relief. } \\
\text { Bark extract is mixed with wild pork fat is applied over } \\
\text { the fractured site and tighten with a cloth. }\end{array}$ \\
\hline 118 & $\begin{array}{l}\text { Holostemma ada-kodien } \\
\text { Schult }(20,21) \\
\text { (Apocynaceae) }\end{array}$ & $\begin{array}{l}\text { Adapathiyan, } \\
\text { jivani, jivanthi }\end{array}$ & $\begin{array}{l}\text { Adapothiyan, } \\
\text { palaikkirai }\end{array}$ & $\begin{array}{l}\text { Used for the treatment of diabetes mellitus, this is the } \\
\text { drug of choice for emaciation, weakness, fever, difficult } \\
\text { breathing, burning sensation in the body, and fertility } \\
\text { issues. It enhances life, vigor, and fertility. }\end{array}$ \\
\hline 119 & $\begin{array}{l}\text { Entada gigas (L.) (22) } \\
\text { (Fabaceae) }\end{array}$ & $\begin{array}{l}\text { Kakkumkai,Par } \\
\text { andakkai }\end{array}$ & Thellukkai & $\begin{array}{l}\text { The seed preparations are used as a nutritive } \\
\text { supplement in jaundice. } \\
\text { It can be administrated with either milk or rice water. It } \\
\text { can be used as gruel also. }\end{array}$ \\
\hline 120 & $\begin{array}{l}\text { Trichopus zeylanicus } \\
\text { Gaertn }(23,24) \\
\text { (Dioscoreaceae) }\end{array}$ & ArogyaPacha & Arogyapachi & $\begin{array}{l}\text { The whole plant is shaded, dried, powdered, and mixed } \\
\text { with distilled water. } \\
\text { Indication: Obesity }\end{array}$ \\
\hline 121 & $\begin{array}{l}\text { Simarouba glauca DC. (25) } \\
\text { (Simaroubaceae) }\end{array}$ & LakshmiTaru & Swargamaram & $\begin{array}{l}\text { A decoction is taken internally in the treatment of } \\
\text { diarrhea, dysentery, malaria, fevers, hemorrhages, } \\
\text { intestinal parasites, and colitis. }\end{array}$ \\
\hline 122 & $\begin{array}{l}\text { Cnidoscolus } \\
\text { aconitifolius(Mill.)I.M.Johns } \\
\text { t(26) } \\
\text { (Euphorbiaceae) }\end{array}$ & Chayamansa & - & $\begin{array}{l}\text { It is used to control body weight and cholesterol and } \\
\text { also Chaya leaves improve glucose metabolism and } \\
\text { prevent diabetes }\end{array}$ \\
\hline 123 & $\begin{array}{l}\text { Hydnocarpous alpine Wight } \\
\text { (27) } \\
\text { (Achariaceae) }\end{array}$ & kattu Marotti & $\begin{array}{l}\text { Malaivatti, } \\
\text { korangu thalai }\end{array}$ & Seed oil is used to cure skin diseases. \\
\hline 124 & $\begin{array}{l}\text { Decalepis arayalpathra(J. } \\
\text { Joseph\&V.Chandras.)Venter } \\
(28) \\
\text { (Apocynaceae) }\end{array}$ & $\begin{array}{l}\text { Janaki arrayal } \\
\text { Patra }\end{array}$ & Amritha pala & $\begin{array}{l}\text { Fresh tuberous root juice is mixed with an equal } \\
\text { quantity of the juice of coconut kernel.it is boiled for } \\
\text { some time and administered as a dose of } 10-15 \mathrm{ml} \text {, } \\
\text { twice daily for } 30 \text { days to cure peptic ulcers. It acts as a } \\
\text { rejuvenating tonic and improves the strength and } \\
\text { stamina of the body. }\end{array}$ \\
\hline 125 & $\begin{array}{l}\text { Argyreia nervosa } \\
\text { (Burn.f.)Bojer (29) } \\
\text { (Convolvulaceae) }\end{array}$ & Samudra Pacha & $\begin{array}{l}\text { Kadarpalai, } \\
\text { samudrapalai }\end{array}$ & $\begin{array}{l}\text { It is used in the treatment of rheumatism. The leaf is } \\
\text { applied to the inflamed part. It accelerates suppuration } \\
\text { while the upper smooth surface helps in wound healing. }\end{array}$ \\
\hline 126 & $\begin{array}{l}\text { Begonia malabarica Lam. } \\
\text { (30) } \\
\text { (Begoniaceae) }\end{array}$ & $\begin{array}{l}\text { Kaiyyalapuli, } \\
\text { janankolli, } \\
\text { enamkolli, } \\
\text { Rakthasuri, }\end{array}$ & $\begin{array}{l}\text { Narayana } \\
\text { sanjeevi }\end{array}$ & $\begin{array}{l}\text { Leaf paste is applied gently covering the entire foot for } \\
\text { tinea pedis (Settrupun). Dried aerial parts of plants are } \\
\text { made a paste with coconut oil is taken to rheumatic } \\
\text { pain. Kanikkar uses the fresh leaf juice of this plant } \\
\text { with salt to treat giddiness. The fresh leaf juice is taken } \\
\text { orally on empty stomach to relieve stomach pain. }\end{array}$ \\
\hline 127 & $\begin{array}{l}\text { Aristolochia tagala Cham. } \\
\text { (31) } \\
\text { (Aristolochiaceae) }\end{array}$ & Malayarayan & Perumooli & Root and leaf paste is used for Snake poison. \\
\hline
\end{tabular}

Regarding the plants mentioned by respondents, the most cited families were Fabaceae with 12 species followed by Euphorbiaceae ( 7 species), Zingiberaceae and Apocynaceae (6 species), Malvaceae (5 species), whereas Verbenaceae, Menispermaceae, Asclepiadaceae, Solanaceae, Lamiaceae, Asteraceae and Liliaceae (4 species), Piperaceae, Acanthaceae, Rutaceae, Aristolochiaceae, Moraceae and Caesalpiniaceae (3 species), Moringaceae, Dioscoreaceae, Meliaceae, Sterculiaceae, Amaranthaceae and Convolvulaceae (2 species), and 33 families were represented with single binomial species ( Table.no -2).

Table 2: Represented Families with single-member and their binomial

\begin{tabular}{c|c|c|c|c|c|}
\hline $\begin{array}{c}\text { Sl } \\
\text { No }\end{array}$ & Family & Binomial Name & $\begin{array}{c}\text { Sl } \\
\text { No. }\end{array}$ & Family & Binomial Name \\
\hline 1 & Guttiferae & Caryophyllum inophyllum L. & 18 & Polygalaceae & Polygala glabra B.Heyne ex A.W.Benn. \\
\hline 2 & Rhamnaceae & Ventilago maderaspatana Gaertn. & 19 & Costaceae & Costus speciosus (J.Koenig) Sm. \\
\hline 3 & Myrtaceae & Syzygium cumini (L.) & 20 & Simaroubaceae & Simarouba glauca DC. \\
\hline
\end{tabular}




\begin{tabular}{|c|c|c|c|c|c|}
\hline 4 & Mimosaceae & Mimosa pudica L. & 21 & Rubiaceae & Chasalia curviflora(Wall.) \\
\hline 5 & Cucurbitaceae & Trichosanthes curcumina L. & 22 & Nyctaginaceae & Boerhavia diffusa L. \\
\hline 6 & Begoniaceae & Begonia malabarica Lam. & 23 & Brassicaceae & Terminalia chebula Retz. \\
\hline 7 & Musaceae & Musa paradisiaca L. & 24 & Myristicaceae & Knema attenuate Warb. \\
\hline 8 & Boraginaceae & Heliotropium indicum L. & 25 & Smilaceae & Smilax chinensis L. \\
\hline 9 & Colchichaceae & Gloriosa superba L. & 26 & Poaceae & Cynodon dactylon (L.) pers. \\
\hline 10 & Celastraceae & Celasia oblanga L. & 27 & Oxalidaceae & Oxalis corniculata L. \\
\hline 11 & Plumbaginaceae & Plumbago rosea $L$ & 28 & Aizoaceae & Glinus lotoides L. \\
\hline 12 & Amaryllidaceae & Curculigo orchioids Gaertn. & 29 & Vitaceae & Cissus quadrangularis $L$. \\
\hline 13 & Acharidaceae & Hydnocarpus alpine Wight & 30 & Umbelliferae & Centella asiatica (L.) \\
\hline 14 & Sapotaceae & Mimusops elengi L. & 31 & Geraniaceae & $\begin{array}{c}\text { Biophytum sensitivum (L.) } \\
\text { sensitivum }\end{array}$ \\
\hline 15 & Scrophulariaceae & Bacopa monnieri (L.) & 32 & Sapindaceae & Cardiospermum halicababaum L. \\
\hline 16 & Cyperaceae & Scleria lithosperma (L.) & 33 & Anacardiaceae & Anacardium occidentale L. \\
\hline 17 & Plantaginaceae & Scoparia dulcis L. & & & \\
\hline
\end{tabular}

\section{Fig.no: -2: Ailments treated in Kani settlements}

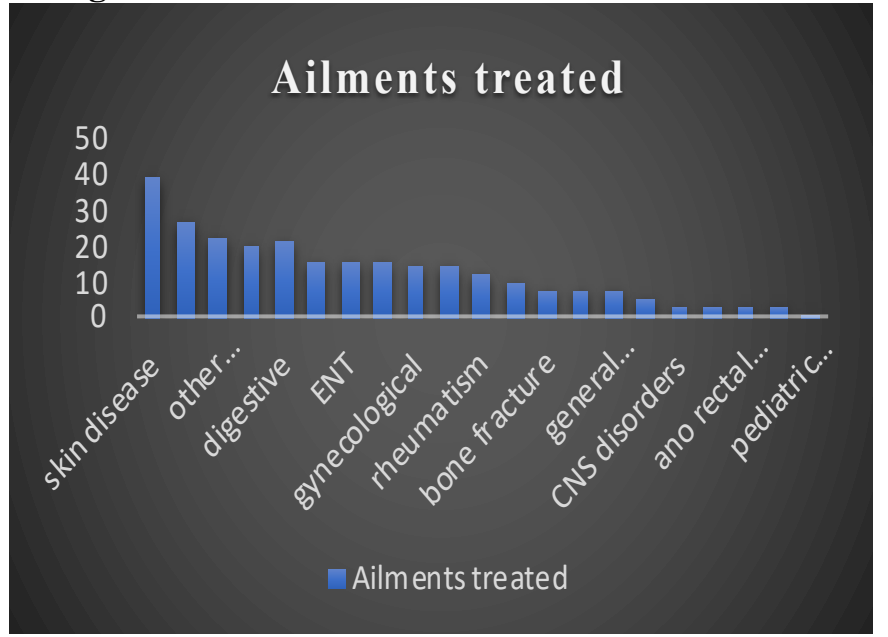

Traditional healers are using plants to cure diseases like Toxic fever, Burns, Asthma, Tuberculosis, Urinary tract infection (UTI), kidney stone, Sebaceous cyst, Trauma, Bone fracture, Uterine disorders, ENT disorders, Obesity, Diabetes mellitus, Ano-rectal disorders, Cholera and toxic conditions (snake bite, scorpion bite, spider bite and all type of poisonous bites).

Fig. no: 3: Plant parts used for the preparation of medicines in Kani settlements.

\section{Plant parts used for treatments}

100

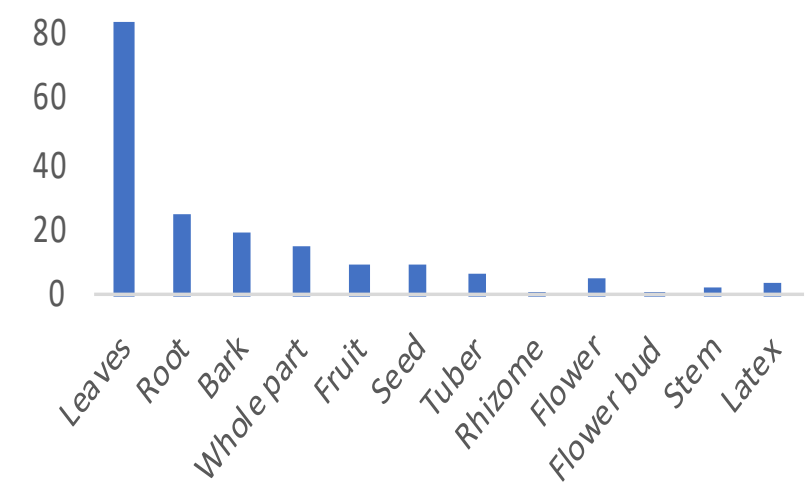

The result of the present study provides evidence that the most frequently used plant parts are leaves followed by root, bark, whole plant, fruit, seed, tuber (Fig. no: 3). Most of the traditional healers use plants that are easily accessible and available for the treatment of common illnesses. It can also be noted that some medicinal plants were used in more than one form of preparation. Various plant parts are also used in the form of decoction, pills, paste, or powder. Most of the medicines are administrated with additives like honey or coconut milk or jaggery or cow's milk.it was observed that different plants have different routes of administration. Certain forms of medicines are taken orally $(46 \%)$. While most of the plant parts are utilized as external applications (54\%).

Kani tribes and traditional healers of Peringamala panchayath were used different parts of medicinal plants as medicine. The present study documented 127 medicinal plants which belong to 57 families. The most cited family was Fabaceae. This result is in agreement with P Nusaifa Beevi et al., (10) who documented a total of 101 medicinal plants used by the Kani tribes in two settlements of Peringamala panchayath where the majority, belonged to Fabaceae. Most of the collected plants were herbaceous, followed by shrub (25\%), trees (22\%), Climber (16\%) (Fig. no: 4). The plants under study were utilized for curing diseases like cure diseases like Toxic fever, Burns, Asthma, Tuberculosis, Urinary tract infection (UTI), kidney stone, Sebaceous cyst, Trauma, Bone fracture, Uterine disorders, ENT disorders, Obesity, Diabetes mellitus, Ano-rectal disorders, Cholera and toxic conditions (snake bite, scorpion bite, spider bite and all type of poisonous bites). Simple formulations followed by traditional healers of Peringamala panchayath are mentioned in Table.no - 3. Some medicinal plants used by Kani tribes such as Keeri kizhangu (Anaphyllum beddomeii), Echaramooli (Aristolochia indica), Perumooli (Aristolochia tagala), Kiranthinayakam (Ruellia patula) for treating toxic conditions (Table.no - 4). 
Table.no - 3: Simple Herbal Formulations, followed by traditional healers of Peringamala Panchayath.

\section{Sl. No Disease/ symptoms Formulations}

- Take Uthamani charu (juice of Pergularia daemia) and mix with honey in equal quantity and given twice a day.

$1 \quad$ Recurrent fever

- An equal quantity of Chukku (Zingiber officinale), Milagu

- (Piper nigrum), Thippili (Piper longum), Kadukkai (Terminalia chebula) is taken added with jaggery and made into pills and It is administrated twice a day with honey.

- Take Veppilai (Azadirachta indica), Siruvengayam (Allium cepa) Milagu (Piper nigrum),

$\begin{array}{ll}\text { Toxic fever } & \begin{array}{l}\text { Vetrilai (Piper betle) in equal quantity } \\ \text { it. } \quad \text { Dosage: } 15-30 \mathrm{ml} \text { twice a day }\end{array} \\ \text { - Morasankodi (Diploclisia glaucesens) }\end{array}$

3 Burns

- Morasankodi (Diploclisia glaucesens) leaves are fried, powdered, made into a paste, and applied over the affected area.

- Take an equal quantity of Vetrilai Charu (Piper betle), Inji charu (Zingiber officinale) mixed

$4 \quad$ Asthma with honey and administrated twice a day.

- Nilappanai kizhangu (Curculigo orchiodes) is washed, dried, powdered and about $5 \mathrm{gm}$ powder is made into pills with coconut milk, which is administrated with Luke warm water.

- Vishnukiranthi (Evolvulus alsinoides) samoolam is dried in shade, powdered, and mixed with jaggery which is administrated twice a day.

- 20gm of keezhanelli (Phyllanthus niruri) samoolam is crushed into a paste and consumed on Phlegm empty stomach with cows' milk or coconut milk.

5 accumulation in the chest

- Muyalsevi samoolam (Emilia sonchifolia) samoolam is applied over the throat and neck.

- Adathodai (Justicia adhatoda) Karinotchi(Vitex negundo) leaves are made into a paste and mixed with coconut milk. It is taken to cure cough and chest pain and administer twice a day.

6 Tuberculosis $\quad$ - 5gm of Athimathuram (Glycyrrhiza glabra) is consumed with milk.

Urinary tract

7 infection (UTI),

kidney stone.

- Kalluruki (Scoparia dulcis) samoola charu is given twice a day (5 ml)

- Murungai (Moringa oleifera) ilai chaaru mixed with milagu (Piper nigrum) which is applied over the affected area.

$8 \quad$ Headache

- $20 \mathrm{gm}$ fresh root of Garudakodi (Aristolochia indica) along with 5gm of Maramanjal (Coscinium fenestratum) crushed to paste and applied over the forehead.

- Two drops of Thumbai (Leucas aspera) poo chaaru is instilled into the nose (Nasiyam)

- Vakkathipullu (Scleria lithosperma) kizhangu is washed, baked, powdered, and mixed with coconut oil and applied over the infection.

- Apply a mixture of Morasankodi (Diploclisia glaucesens) leaves, gingelly oil, coconut oil on the affected area.

$10 \quad$ Sprain

- Ellottipattai (Pterospermum rubiginosum) is crushed and kept on a clean cloth and heated over a hot mud utensil at a mild temperature. It is gently applied over the affected area.

- Apply paste made of:

Vallarai (Centella asiatica)

Murungai iliai (Moringa oleifera)

Uppu (Salt), Vathamadakki (Boerhavia diffusa)

11 Acute inflammation

Siruvengayam(Allium cepa) over affected area.

- Neerootikizhangu (Chlorophytum laxum) paste is applied over the affected area.

- Moosambaram (Aloe barbadensis) is mixed with egg white and applied over the inflamed area.

- Thottalsinungi (Mimosa pudica) samoolam is mixed with Kalluppu(Rock salt) and Arikkadi (rice-washed water) and applied.

12 Bone fracture

- The bark of Ellootti (Pterospermum rubiginosum) after removing the outer dead layer is crushed to paste with lukewarm water. The bone is held back into the normal position and the paste is applied over the affected area.

Pancha moola sanjeevi:

- Sivakaranthai choornam (Sphaeranthus amaranthoides)

- Keezhanelli samoolam (Phyllanthus niruri)

- Arisithippili (Piper longum)

13 Nervine tonic

- Vasambu (Acorus calamus)

General health

- Seenthil samoolam (Tinospora cordifolia)

All the ingredients are taken in equal quantity, to be mixed and preserved in a clean bottle.

Dose: 2-4 grains, twice a day, 40 days

Adjuvant: honey

- Take Peruvalam (Cleodendrum infortunatum) tender leaves, crushed into a paste with a little amount of lime, and applied over wound.

14 Trauma

- A mixture of Thottarsinugi (Mimoosa pudica), Tintanali (Biophytum sensitivum) leaves paste is applied over the affected area.

- Murungai (Moringa oleifera) pattai is ground with Kadugu

- (Brassica nigra) mixed with salt and applied over the affected area. 


\begin{tabular}{|c|c|c|}
\hline 15 & Abrasions & - Vettukayapoondu (Tridax procumbens) leaves are ground and applied over the affected area. \\
\hline 16 & Uterine disorders & - Thengin poo kula rasayanam (Ayurvedic preparation made from Coconut inflorescence) \\
\hline 17 & Anemia & - Enamkolli (Begonia malabarica) leaf juice mixed with ginger juice is given. \\
\hline 18 & Otalgia & $\begin{array}{l}\text { - Koshtam (Costus speciosus) stem extract is heated, mixed with lukewarm water, and } \\
\text { instilled as ear drops. } \\
\text { - Vilvam (Aegle marmelos) leaf extract is heated with gingelly oil and instilled as ear drops. } \\
\text { - Oil preparation of Karinotchi (Vitex negundo) leaf extract is applied daily on the head. } \\
\text { - Milky latex of Ezhilampalai (Alstonia scholaris) is mixed with oil and is slowly dropped } \\
\text { into the ear. }\end{array}$ \\
\hline 19 & Conjunctivitis & - Leaf extract of Neichitti (Vernonia cinerea) is used as an ear drop. \\
\hline 20 & Toothache & $\begin{array}{l}\text { - Kuravan kandamooli (Thottea siliquosa) root is made into a paste and is applied over the } \\
\text { affected area. }\end{array}$ \\
\hline 21 & Spinter in throat & - Mullurukki (Ipomea quamoclit) leaf paste is applied over the throat. \\
\hline 22 & Obesity & $\begin{array}{l}\text { - Arogya pachi (Trichopus zeylanicus) samoolam is dried, powdered, and consumed with } \\
\text { water. } \\
\text { - Plant extract of Brahmi (Bacopa monnieri) is mixed with honey and taken. }\end{array}$ \\
\hline 23 & Piles & - Pata (Cyclea peltata) root powder is mixed with curd, intake one spoon daily. \\
\hline 24 & Diabetes mellitus & $\begin{array}{l}\text { - Nilappanai kizhangu (Curculigo orchioides) root is dried, powdered and about } 5 \mathrm{gm} \text { is made } \\
\text { into pills with coconut milk and administrated with lukewarm water. } \\
\text { - Adapathiyan (Holostemma adakodein) is dried, powdered, and administrated with lukewarm } \\
\text { water. Dosage: } 2 \mathrm{gm} \\
\text { - A mixture of Seenthil(Tinospora cordifolia) extract (15ml) and half spoon turmeric powder } \\
\text { is taken. }\end{array}$ \\
\hline 25 & $\begin{array}{l}\text { Body itching and } \\
\text { psoriasis } \\
\text { Skin disease }\end{array}$ & $\begin{array}{l}\text { - Karudankizhangu ennai (Aristolochia indica) can be applied over the lesion. } \\
\text { - Erukkan paal (Calotropis gigantea) is applied over the rashes, Chirattai thylam can be } \\
\text { applied externally. }\end{array}$ \\
\hline 26 & Cholera & $\begin{array}{l}\text { - Fruit extract of Munthiri (Anacardium occidentale) is kept in a glass bottle and placed in a } \\
\text { dung pit for } 6 \text { months and taken.it is administrated with half spoon of salt. }\end{array}$ \\
\hline 27 & Tinea pedis & - Enamkolli (Begonia malabarica) leaf paste is applied over the affected area. \\
\hline 28 & Warts & $\begin{array}{l}\text { - Puliyarai(Oxalis corniculata) iliai extract and Vengayam (Allium cepa) ilai extract are } \\
\text { mixed and applied over the area. }\end{array}$ \\
\hline 29 & Premature grey hair & $\begin{array}{l}\text { - The inner part of the wood of Vengai (Pterocarpus marsupium) is boiled in gingelly oil and } \\
\text { applied to the scalp. }\end{array}$ \\
\hline 30 & Promote lactation & $\begin{array}{l}\text { - } 20 \mathrm{gm} \text { of Adapathiyan (Holostemma adakodein) kizhangu paste is consumed with cow's milk } \\
\text { on empty stomach. } \\
\text { - } 30 \text { gm of Nilappanai kizhangu (Curculigo orchioides) paste is consumed with cow's milk on } \\
\text { empty stomach. } \\
\text { - Thumbai (Leucas aspera) poo chaaru is mixed with milk and boiled to make a paste. }\end{array}$ \\
\hline
\end{tabular}

Table.no - 4: Plants used for treating Toxic conditions by Traditional healers.

\begin{tabular}{|c|c|c|}
\hline Sl. No & Disease & Treatment \\
\hline 1 & Snakebite & $\begin{array}{l}\text { - Decoction of Valampuri(Helicteres Isora) kai is administrated at a dose of } 15-30 \mathrm{ml} \text { twice a } \\
\text { day } \\
\text { - Juice of Siriyanangai (Polygala arvensis) leaves ( } 50 \mathrm{ml} \text { ) with milagu (Piper nigrum) (2) is } \\
\text { given twice a day } \\
\text { - Akayagarudan (Corallocarpus epigaeus) paste is rubbed between the bamboo sticks and } \\
\text { applied over the affected area. } \\
\text { - Neerooti kizhangu (Chlorophytum laxum) paste is applied over the affected area. } \\
\text { - Tribals use poison stone (a ball, made of certain medicine) to drain off the venom. The stone is } \\
\text { attached to the wound and it detaches off only when it has drained off the entire venom. the } \\
\text { patient is given a bath in hot water only after the stone is detached. }\end{array}$ \\
\hline 2 & Spider bite & $\begin{array}{l}\text { - } 50 \mathrm{ml} \text { fresh leave extract of Kiranthinayakam (Ruellia patula) is taken along with an equal } \\
\text { volume of cow's / coconut milk and the leaf paste is applied over the affected area. }\end{array}$ \\
\hline 3 & Scorpion sting & - The extract of Thelkodukkilai (Heliotropium Indicum) extract will be given. \\
\hline 4 & $\begin{array}{l}\text { All kinds of } \\
\text { poisonous bites }\end{array}$ & $\begin{array}{l}\text { - } 10 \mathrm{gm} \text { of Avuriver(Intigofera tinctoria) is heated with } 240 \mathrm{ml} \text { of water, reduced to } 1 / 4 \text {, and made } \\
\text { into a decoction. } \\
\text { Dose: } 15 \mathrm{ml} \text { twice a day. }\end{array}$ \\
\hline 5 & $\begin{array}{l}\text { All kinds of } \\
\text { poisonous bites, } \\
\text { food poison }\end{array}$ & $\begin{array}{l}\text { Astamoolam koottu: } \\
\text { 1. Korai kizhangu (Cyperus rotundus) } \\
\text { 2. Vishnu kiranthi (Evolvulus alsinoides) } \\
\text { 3.Peipudal (Trichosanthes cucumerina) } \\
\text { 4. Seenthil (Tinospora cordifolia) } \\
\text { 5. Kanjan korai (Ocimum canum) } \\
\text { 6.Adathodai (Adathoda vasica) } \\
\text { 7.Thulasi (Ocimum sanctum) } \\
\text { 8.Parpadagam (Mollugo cerviana) } \\
\text { It can act as a blood purifier and neutralizes the toxic effects of any poisonous bites. }\end{array}$ \\
\hline
\end{tabular}


The method of preparation (Fig. no:5) falls into six categories, viz juice extract from the fresh plant parts $(38 \%)$, plant parts applied as a paste $(28 \%)$, decoction $(13 \%)$, a powder made from fresh or dried plant parts $(11 \%)$, oil $(8 \%)$, pills $(2 \%)$. External applications are mostly used for skin diseases, snake bites, wounds, and internal consumption of the preparations were involved in the treatment of different ailments. Information was collected from the traditional healers and Kani tribes that share knowledge of the method of preparation and route of administration of plants to cure ailments.

Fig. no- 4: Habit of collected plants

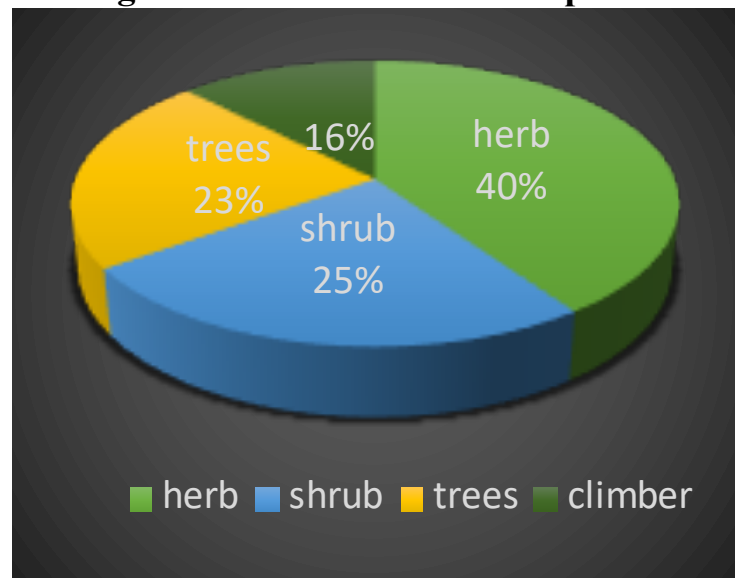

Fig. no-5: Method of preparation

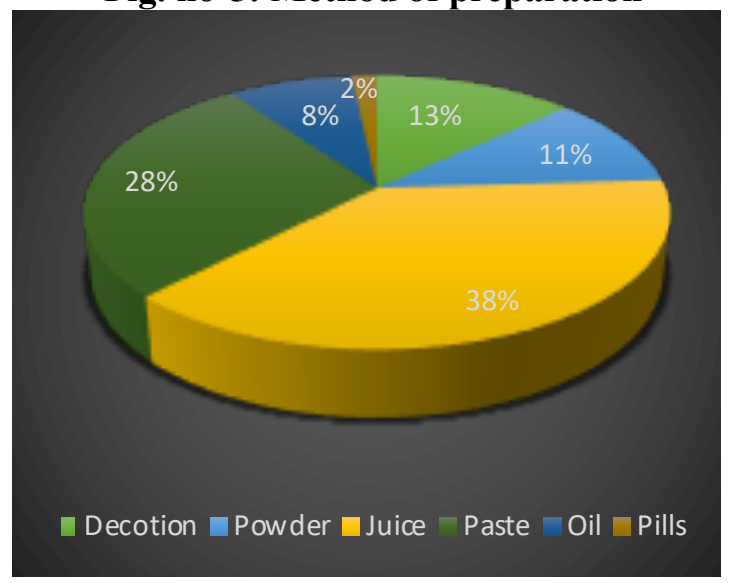

\section{Conclusion}

This survey denoted that the study area has plenty of medicinal plants which can be used to treat a wide spectrum of ailments. They have good knowledge about the usage of medicinal plants that have been passed orally from generation to generation. Methods used to collect ethnomedicinal data were included semistructured interviews, field visits with local knowledgeable persons. Informants have shared their ethnomedicinal knowledge and asked to mention all the medicinal plants known or used. The present study documented some medicinal plants used by Kani tribes which are included in the list of rare and endangered categories, so special care should be taken to cultivate and conserve these unique plants by making them available for mass cultivation, either through conventional methods or other non-conventional methods like micro propagation and also the study indicated that the current traditional healers may be the final generation in the study area. there is a possibility of losing a wealth of traditional knowledge in near future due to rapid socio-economic and cultural changes. So, it's our responsibility to acquire and preserve the traditional system of medicine by proper documentation and identification of the specimen. The wealth of this tribal knowledge points to a greater potential for the Indian system of medicine towards research and drug discovery.

\section{Acknowledgment}

The authors acknowledge the support and facilities provided by the National Institute of Siddha, Tambaram sanatorium, Kani tribes, and traditional healers of Peringamala Panchayath, Thiruvananthapuram.

\section{References}

1. https://censusindia.gov.in - Scheduled castes and scheduled tribes - Census of India dated 14-07-2021 time 22:03 IST

2. https://www.iqbalcollege.edu.in/images/files/ Summary-3.pdf dated 17-07-2021 time 22:03 IST

3. Purushothaman $T$ et al., Ethnobotanical Medicines Used by the Kani and Kurichiyar Tribal Communities of Kerala, Shanlax International Journal of Arts Science and Humanities 8(1):191-199

4. https://totemngo.wordpress.com/tribes-of-kerala/ dated 17-07-2021 time 22:20 IST

5. https://www.iqbalcollege.edu.in/images/files/ Summary-3.pdf dated 17-07-2021 time 22:03 IST

6. Chellappan Biju V et al., Therapeutic properties of Trichopus zeylanicus Subsp.of Trichopus zeylanicus Subsp. travancoricus, a Rare, Endangered Medicinal Plant in South India: A Review, Herbal Medicine Vol.5 No.1:2 2019

7. Pushpangadan $\mathrm{P}$ et al., 'Arogyappacha'(trichopus zeylanicus gaerin), The 'Ginseng' of Kani tribes of Agasthyar hills (Kerala) for evergreen health and vitality, Ancient Science Life. 1988 Jul-Sep; 8(1): $13-16$

8. http://www.stdd.kerala.gov.in/sites/default/files/ inline-files/surveyd_2008.pdf, dated 20-07-2021 time 10.15 IST

9. https://en.wikipedia.org/wiki/Peringamala dated 20-07-2021 time 10.30IST

10. Nusaifa Beevi $P$ et al., A study on ethnomedicinal plants of two Kani tribal settlements of Peringamala panchayat, Kerala, International research journal of natural and applied sciences, volume 5 issue 2 February 2018.

11. Lei Fang et al., Isolation and Purification of Three Ecdysteroids from the Stems of Diploclisia glaucescens by High-Speed Countercurrent Chromatography and Their Anti-Inflammatory Activities In Vitro, Molecules. 2017 Aug; 22(8): 1310. 
12. Douglas lobby et al., Rauwolfia in the Treatment of Hypertension, Integr Med (Encinitas). 2015 Jun; 14(3): 40-46.

13. Dharsana $\mathrm{J} \mathrm{N}$ et al., preliminary evaluation of phytochemical and antiinflammatory study of various extracts of tuber of Anaphyllumwightii Schott by in vitro HRBC membrane stabilizing activity, International Journal of Pharmacy \& Life Sciences, 5(4): April, 2014:3474-3477

14. Lakshmi $\mathrm{S}$ et al., In vitro anticancer potential of Anaphyllum wightii Schott. against Dalton's lymphoma ascites cell lines and molecular docking studies of $\beta$-sitosterol, Indian journal of experimental biology (IJEB), Vol 58, No 08 (2020)

15. Saiba Abdul Wahab Nusaiba and Kumaraswamy Murugan et al., In vitro analysis on bactericidal screening and antioxidant potentiality of leaf and root extracts of Thottea siliquosa (Lam.) Ding Hou. An ethnobotanical plant, Asian Pac J Trop Biomed. 2013 Nov; 3(11): 859-865.

16. Chavan Jayakumar J et al., In vitro propagation of Ceropegia spiralis Wight - An endemic and rare potential ornamental plant of peninsular India, Proceedings of the National Academy of Sciences, India - Section B: Biological Sciences 81:120-126

17. Supriya raja $\mathrm{H}$ et al., Phytopharmacological Review of Knema Attenuata (Hook F. And Thomson) Warb, Int J Curr Pharm Res, Vol 13, Issue 3, 1-3

18. Krishna Ajeesh et al., Pharmaco-Chemical Characterization and Acaricidal Activity of Ethanolic Extract of Chassalia curviflora(Wall Ex Kurz.) Thwaites, Pharmacognosy Journal, VOL 8, ISSUE 3, MAY-JUN, 201; 215-219.

19. Jacob Jenson et al., Antioxidant and antiinflammatory properties of Pterospermum rubiginosum Heyne ex wight and arn and Pterospermum reticulatum wight and arn (Sterculiaceae): an in vitro comparative study, Asian Journal of Pharmaceuticals and Research, VOL 12 ISSUE 2 FEBRUARY 2019

20. Deepak M et.al, Characterization of Terpenoids Phenolic and Coumarin Compounds from Indian Medicinal Plant Holostemma ada kodien and Its Antioxidant Activity, Analytical Chemistry Letters Volume 9, 2019 Issue 6

21. Mallikarjuna $B$ et.al evaluated the in vitro antioxidant activities of hexane, ethyl acetate, and methanolic extracts of Holostemma adakodien root tubers.

22. Akindele et al, Gastroprotective Effects of the Aqueous Seed Extract of Entada gigas (Linn.) Fawc. and Rendle (Fabaceae) in Ulcer Models in Rats, African Journal of Pharmacology and Therapeutics Vol. 5 No. 3 Pages 155-162, 2016

23. Binu Tharakan et al., Antioxidant and DNA protecting properties of anti-fatigue herb Trichopus zeylanicus, Phytother Res. 2005 Aug;19(8):669-73.

24. Sivanandham Velavan et al., Cardioprotective effect of Trichopus zeylanicus against myocardial ischemia induced by isoproterenol in rats, Bangladesh journal of pharmacology, Vol 4 No 2 (2009)

25. Asha Jose et al., Tricaproin Isolated from Simarouba glauca Inhibits the Growth of Human Colorectal Carcinoma Cell Lines by Targeting Class-1 Histone Deacetylases, Front Pharmacol. 2018; 9: 127

26. Ivan Moises Sanchez-Hernandez et al., Nutraceutical Potential of Cnidoscolus aconitifolius, ARC Journal of Nutrition and Growth, Volume-3 Issue-2, 2017, Page No: 27-30

27. Ganesh mani et al., Hydnocarpus alpina Wt extract mediated green synthesis of $\mathrm{ZnO}$ nanoparticle and screening of its anti-microbial, free radical scavenging, and photocatalytic activity, Biocatalysis and Agricultural Biotechnology Volume 19, May 2019, 101129

28. Sudha $\mathrm{C} \mathrm{G}$ et al., In vitro propagation of Decalepis arayalpathra, a critically endangered ethnomedicinal plant, In Vitro Cellular \& Developmental Biology

Plant volume 41, pages648-654

29. Singhal A K et al., Wound healing activity of Argyria nervosa leaves extract, Int J Appl Basic Med Res 2011 Jan;1(1):36-9.

30. Ramesh $\mathrm{N}$ et al., Phytochemical and antimicrobial studies of Begonia malabarica, Journal of Ethnopharmacology 79(2002):129-32

31. Rajani M B et al., A review on medicinal uses, pharmacology and phytochemistry of Aristolochia tagala Cham. An endangered medicinal plant, Journal of Pharmacognosy and phytochemistry 2020; 9(4): 580-583 